\title{
Effect of Humor Therapy on Chronic Pain: A Literature Review
}

\author{
Yusnaeni Y, Kadek Ayu Erika, Rini Rachmawaty \\ Magister of Nursing Science, Hasanuddin University, South Sulawesi, Indonesia \\ Corresponding author: enhirfan@gmail.com
}

\begin{abstract}
Background: Chronic pain is an unpleasant sensory and emotional experience with actual or potential tissue damage, or is described as a damage lasting more than 3 months with heavy or moderate intensity. The patient's response to the pain he experienced was done in different ways such as shouting, grimacing, crying, etc. Repair of pain is likely to occur more quickly when psychological intervention is included in medical care because it requires alternative and complementary treatment to overcome the pain including prayer, humor, hypnosis, and group support. Growing evidence-based nursing practice shows progress in helping patients deal with the pain. One of the evidence-based nursing practices is humor therapy.
\end{abstract}

Method: The literature search was done through searching the results of scientific publications 2010-2018 using several databases, such as Such as Google scholar, PubMed, DOAJ, and Cochran, with keyword "Humor Therapy and Chronic Pain.

Result: Obtained 6 fulltext articles, were obtained with various methods used, such as quasi-experimental pre- and posttest control group design, randomized two-group review literature, concluded that humor therapy proved effective in reducing chronic pain in all ages.

Conclusion: The humor therapy is effective in reducing chronic pain in patients of all ages, both children, adults and the elderly, besides humor therapy can also be used to increase endurance and quality of life in elderly who are cared for in nursing homes.

Keywords : Chronic Pain, Humor Therapy, Literature Review.

Received: January 12, 2019; Revised : February 24, 2019; Accepted March 14, 2019

How to Cite: Yusnaeni, Y., Erika, K.A., \& Rachmawaty, R. (2019). Effect of Humor Therapy on Chronic Pain: A Literature Review. Journal Of Nursing Practice. 2(2). 97-101. https://doi.org/10.30994/jnp.v2i2.51 


\section{BACKGROUND}

Chronic pain is an unpleasant sensory and emotional experience with actual or potential tissue damage, or described as a damage lasting more than 3 months with severe or moderate intensity (Herdman \& Kamitsuru, 2018).

The patient's response to the pain he experienced was done in different ways such as shouting, grimacing, crying, etc., while the physiological reaction to pain is divided into sympathetic stimulation response characterized by dilatation of bronchial blood vessels and increased respiratory rate, increased heart rate, increased sugar levels blood, diaphoresis, increased muscle tension, pupillary dilatation, and decreased digestive movements. While parasympathetic stimulation response is characterized by palor, muscle tension, decreased heart rate and blood pressure, and rapid and irregular breathing (Potter \& Perry, 2010).

Pain perception is influenced by an individual's tolerance of pain. To understand the tolerance, people must distinguish between the limits of pain and pain tolerance. The limit of pain is perceived as the lowest intensity of a painful stimulus that can vary depending on physiological factors, but is basically the same for all individuals if the central and peripheral nervous systems are normal (Sherwood, 2016).

Moderate to severe chronic pain occurs in $19 \%$ of European adults, which greatly affects the quality of their social life and work. Scrimpy of people are managed by pain specialists and almost half receive inadequate pain management (Breivik, Collett, Ventafridda, \& Cohen, 2006).

In Indonesia, chronic pain is not included in basic health research, but based on data on cancer in Indonesia which is the most common cause of acute pain. It is estimated that annual cancer cases will increase from 14 million in 2012 to 22 million in the next two decades.

The journey of pain includes a series of complex neurophysiological processes referred to as nociception which reflects four real component processes, namely transduction, transmission, modulation and perception, where the occurrence of strong stimuli in peripheral until the pain is felt in the central nervous system (cortex cerebri) (Sherwood, 2016)

Chronic pain has significant consequences for patients, as well as for their families, their social and professional environment, leading to a decline in the quality of life of patients and those close to them (Salazar, Mico, \& Failde, 2016).

Restoration of pain is likely to occur more quickly when psychological interventions are included in medical care because it requires alternative and complementary treatment to overcome the pain including prayer, humor, hypnosis, and group support. The improvement evidence-based nursing practice shows progress in helping patients deal with the pain. One of the evidence-based nursing practices is humor therapy.

The synthesis of 20 studies shows that humor is an effective nursing intervention and has a large potential impact on the health and well-being of patients in various situations, namely a decrease in pain, quality of life, psychology, and an increase in the immune system (Christie \& Moore, 2004).

Humor therapy has been defined as "any intervention that promotes health and well-being by stimulating pleasant acceptance, expression, or appreciation of the absurdity or incompatibility of life situations. This intervention can improve health or be used as a complementary treatment in a disease to facilitate healing or prevention, both physical, emotional, cognitive, social, or spiritual (Lindquist, Snynder, \& Tracy, 2014).

Effects of humor therapy on pain are able to stimulate the release of endogenous opiates that inhibit the transmission of information by delta A cell fibers. Inhibition of delta A cell fibers lead to disconnection of pain information delivery from nociceptors to girus post 
central. Slow delivery of pain stimuli lead to a slowing the body's response to pain (Sninder \& Lindquist, 2009).

\section{METHODS}

Literature review is carried out by searching the results of scientific publications using $\mathrm{n}$ several databases, namely Google scholar, PubMed, DOAJ, and Cochran. Google Scholar with the first keyword was "Humor Therapy" found 921 articles then the second keyword using "Chronic pain" found 1,140.00 articles, then the two keywords were combined and found 146 articles filtered in 2010-2018. After the filter is done by looking at the title that corresponds then found two articles found. The second database is Pubmed with the keyword "Humor Therapy" found 7,289 articles limited using a quotation mark and 26 articles appear. Then the second keyword using "Chronic pain" found 104,437 articles, after the first and second keywords are combined, there are 2 articles found. The next database is DOAJ with the first keyword was "Humor Therapy" found 128 articles then keyword 2 using "Chronic pain" found 9042 articles, and then both keywords were combined and found 2 articles. Next using cochrane with the first keyword was "Humor Therapy" found 3,633 articles the second keyword was " chronic pain" found 3,210 articles, then the two keywords are combined so that found 364 articles. However, after searching, there is no article title that matches the keyword are looking for. Overall, the databases found 6 articles that have passed the title screening, duplication, and year.

\section{RESULT}

\section{Chronic Pain Chronic}

Pain is usually considered as pain that lasts more than 6 months or 3 months which is unknown when it will end unless there is slow healing, such as in scorch. Malignant pain is considered a great pain, both acute pain and chronic pain. This category is considered to be included in neuropathy, visceral, internal, and bone pain. Each type of pain can be well managed by specific strategies to deal with the pain (Black \& Hawks, 2014).

Regardless of how patients treat chronic pain, long-term pain can cause disability. Patients with several chronic pain syndromes reported depression, anger, and fatigue (Smeltzer \& Bare, 2011).

\section{Pain Management}

Patients with chronic pain often require pain specialist care, however, pain management is the responsibility of all providers, including primary care physicians. Although there are limited data on how individuals with chronic pain must be treated, there are many treatment options that need to be considered. These people have chronic conditions that will require continuous therapy with regular reassessment to get the best results. If possible, care must be evidence-based. However, care must always be focused on patients with the aim at reducing pain and suffering and improving physical and mental functioning (Ashburn, 1999).

The gate control theory of Melzack and Wall (1965) suggests that pain impulses can be regulated or inhibited by defense mechanisms along the central nervous system. This theory says that pain impulses are delivered when a defense is opened and impulses are blocked when a defense is closed. The effort to close the defense is the basis of pain relief theory.

Humor therapy is one of the evidence- based pain treatments (Behrouz et al., 2017). It is done using some humor media such as videos, comics, etc. 


\section{Effect of Humor therapy on Chronic Pain}

Laugh and humor therapy has been used in health care to achieve benefits related to physiological and psychological health. The implementation of these therapies in the dialysis context is still unclear. Studies from other groups such as children, parents, and people with mental health, cancer, and other chronic conditions were included to inform the application of potential laugh therapy to dialysis populations. Therapeutic interventions can be obtained from funny videos, stories, clown laugh to fabricated laughs and Laugh Yoga. The effects of laugh and humor on depression, anxiety, pain, immunity, fatigue, sleep quality, respiratory function and blood glucose may have applications in the dialysis context and require further research (Bennett et al., 2014). A study in a nursing home in Iran shows that humor therapy can have a positive impact in reducing chronic pain experienced by the elderly living in nursing homes (Tse et al., 2010), besides humor therapy is considered as an uncomplicated method and costeffective that does not require professional staff and skills to improve elderly health in general, and can be used to make the elderly are closer to their families (Behrouz et al., 2017).

Other research also suggests that humor is effective in controlling pain in adults and children, while humor also has a positive effect in enhancing immune function. In his study this study found that watching funny videos reduced children's pain response by assessing their cortisol hormone (Evans, Tsao, \& Zeltzer, 2008).

But research conducted by (Ghafouri, 2016) stated that humor therapy gives patients the opportunity to forget their anxiety and pain, if only for a short period of time, meaning that humor therapy is only to temporarily reduce the patient's pain.

Another study that supports the effectiveness of humor therapy on pain is what is done by (Leise, 2015) which stated that there is a positive relationship between reducing chronic pain in adult patients.

\section{DISCUSSION}

Based on GLOBOCAN estimates, around 14.1 million new cancer cases and 8.2 million deaths occurred in 2012 worldwide due to cancer (Torre, Bray, Siegel, \& Ferlay, 2015). One serious problem in survivors of cancer is to face pain that can come at any time, including breast cancer patients. This is caused by infiltration of tumor cells in painsensitive structures such as bone, soft tissue, nerve fibers, internal organs, and blood vessels. Pain can also be caused by surgical therapy, chemotherapy, or radiotherapy (Schmidt, Hamamoto, Simone, \& Wilcox, 2010)

Pain that persists in cancer patients is common and is often associated with inadequate provision of targeted analgesia (MI Bennett, Rayment, Hjermstad, Aass, \& Caraceni, 2012), so that other treatments are needed to treat pain in patients, pain relief must be done immediately to helping patients get a good quality of life, as well as feeling comfortable.) Cancer pain repair is likely to occur more quickly when psychological interventions are included in medical care (Bruera \& Russel K Pertonoy, 2016). One evidence-based nursing practice is humor therapy in cancer patients.

\section{CONCLUSION}

Based on several studies above can be drawn a conclusion that humor therapy is effective in reducing chronic pain in patients of all ages, both children, adults and the elderly, besides that humor therapy can also be used to increase endurance and quality of life in elderly treated at a nursing home. 


\section{REFERENCES}

Ashburn, M. A. (1999). Management of chronic pain, 353, 1865-1869.

Behrouz, S., Mazloom, S. R., Kooshyar, H., Aghebati, N., Reza, H., \& Vashani, B. (2017). Investigating the Effect of Humor Therapy on Chronic Pain in the Elderly Living in Nursing Homes in, (098 51). https://doi.org/10.22038/EBCJ.2017.24247.1529

Bennett, M. I., Rayment, C., Hjermstad, M., Aass, N., \& Caraceni, A. (2012). Prevalence and aetiology of neuropathic pain in cancer patients : A systematic review. Pain, 153(2), 359-365. https://doi.org/10.1016/j.pain.2011.10.028

Bennett, P. N., Parsons, T., Ben-moshe, R., Weinberg, M., Neal, M., Gilbert, K., ... Hutchinson, A. (2014). Laughter and Humor Therapy in Dialysis, 488-493. https://doi.org/10.1111/sdi.12194

Black, J. M., \& Hawks, J. H. (2014). Keperawatan medikal bedah: manajemen klinis untuk hasil yang diharapkan.

Breivik, H., Collett, B., Ventafridda, V., \& Cohen, R. (2006). Survey of chronic pain in Europe : Prevalence, impact on daily life, and treatment, 10, 287-333. https://doi.org/10.1016/j.ejpain.2005.06.009

Bruera, E. E., \& Russel K Pertonoy. (2016). Cancer Pain Assessment and Management (Second). London: Cambridge University Press.

Christie, W., \& Moore, C. (2004). The Impact of Humor on Patients With Cancer, (June), 211-219.

Evans, S., Tsao, J. C. I., \& Zeltzer, L. K. (2008). Paediatric Pain Management : Using Complementary and Alternative Medicine Complementary and Alternative Medicine for Paediatric Pain, (7), 14-20.

Ghafouri, R. (2016). Humor as a Complementary Therapy: A Narrative Review, 13751380.

Herdman, H., \& Kamitsuru, S. (2018). NANDA-I Diagnosa Keperawatan Definisi dan

Klasifikasi 2018-2020 (11th ed.). Jakarta: EGC.

Leise, C. Mcm. (2015). The Correlation Between Humor and Chronic Pain of Arthritis.

Lindquist, R., Snynder, M., \& Tracy, mary fran. (2014). Complementary and Alternative therapies in Nursing. (Sevent Edition, Ed.) (New York). Springer Publising Company.

Potter, P. A., \& Perry, A. G. (2010). Fundamental Keperawatan Buku 3 Edisi 7 (Edisi 7). Jakarta.

Salazar, A., Mico, J. A., \& Failde, I. (2016). A review of chronic pain impact on patients, their social environment and the health care system, 457-467.

Schmidt, B. L., Hamamoto, D. T., Simone, D. A., \& Wilcox, G. L. (2010). Mecanisms Of Cancer Pain. Molecular Intervention, 164-178.

Sherwood, L. (2016). Fisiologi Manusia; Dari sel ke sistem (Introduction to Human Physiology). (H. Octavius, A. A. Mahode, \& D. Ramadhani, Eds.) (Edisi 8). Jakarta: EGC.

Smeltzer, \& Bare. (2011). Keperawatan Medikal Bedah. Jakarta: EGC.

Sninder, M., \& Lindquist, R. (2009). Complementary \& Alternative Therapies in Nursing (Sixth Edit). New York: Springer Publishing Company.

Tse, M. M. Y., Lo, A. P. K., Cheng, T. L. Y., Chan, E. K. K., Chan, A. H. Y., \& Chung, H. S. W. (2010). Humor Therapy : Relieving Chronic Pain and Enhancing Happiness for Older Adults, 2010. https://doi.org/10.4061/2010/343574 